\section{FAMILY LITERACY OF BADUY TRIBE: AN ETHNOGRAPHIC STUDY}

\section{LITERASI KELUARGA PADA SUKU BADUY: SEBUAH STUDI ETNOGRAFI}

\author{
Ila Rosmilawati ${ }^{1}$, Dadan Darmawan ${ }^{2}$ \\ ${ }^{1}$ Jurusan Pendidikan Nonformal, Universitas Sultan Ageng Tirtayasa \\ ${ }^{2}$ Jurusan Pendidikan Nonformal, Universitas Sultan Ageng Tirtayasa \\ 3irosmilawati@untirta.ac.id
}

Jurnal Pendidikan Luar Sekolah

http://kolokium.ppj.unp.ac.id/

Jurusan Pendidikan Luar Sekolah

Fakultas Ilmu Pendidikan

Universitas Negeri Padang

Sumatera Barat, Indonesia

Volume 8, Nomor2, 2020

DOI: $10.24036 /$ kolokium-pls.v8i2.434

Received 14 August 2020

Approved 27 October 2020

Published 30 October 2020

\begin{abstract}
The purpose of this ethnographic study was to reveal the family literacy practices of Baduy tribe at Lebak Regency, Banten Province. Family literacy in this paper refers to an intergenerational learning in in Baduy tribe families, which include how family learns, uses reading and writing activities to do daily task, and other literacy activities to maintain family relationship. Family literacy in Baduy is called intergenerational learning in which the learning method that is practiced in families and communities leads to the creation of a process of cultural and educational transformation in a society. This study utilizes ethnographic approach by conducting interviews with sixteen families (father and mother) and eighteen children and youth. Data analysis includes the four stages of ethnographic data analysis, namely domain, taxonomy, component and theme analysis. The results showed that family literacy in the Baduy tribe last a lifetime, starting from children aged 7 days to 10 years. The literacy activities of the Baduy family cannot be separated from the their culture and beliefs. This culture is passed down from generation to generation with an intergenerational learning approach, it is the process of delivering literacy that is practiced directly within the family.
\end{abstract}

Keywords: Baduy tribe, ethnography, family literacy, intergenerational learning

\begin{abstract}
ABSTRAK
Penelitian ini bertujuan untuk mengungkap praktik-praktik literasi keluarga Suku Baduy di Kabupaten Lebak, Provinsi Banten. Literasi keluarga (family literacy) dalam artikel ini merujuk pada pendidikan antar generasi keluarga Suku Baduy yang mencakup bagaimana suatu keluarga belajar, menggunakan aktivitas baca-tulis untuk melakukan tugas sehari-hari, menggunakan aktivitas literasi untuk menjaga hubungan keluarga dan dengan anggota masyarakat lainnya. Literasi keluarga pada masyarakat Suku Baduy termasuk pada pembelajaran antargenerasi atau intergenerational learning, yaitu sebuah metode belajar yang dipraktikkan didalam keluarga maupun masyarakat yang mengarah pada terciptanya proses transformasi budaya dan pendidikan dalam suatu masyarakat. Penelitian ini menggunakan pendekatan kualitatif etnografi dengan melakukan wawancara kepada 16 keluarga (ayah dan ibu) dan 18 anak-anak Suku Baduy. Analisa data mengacu para empat tahap analisis data etnografi, yaitu analisis domain, analisis taksonomi, analisis kompensional dan analisis tema. Hasil penelitian menunjukkan bahwa kegiatan literasi keluarga pada Suku Baduy berlangsung sepanjang hayat, mulai dari anak usia 7 hari sampai usia 10 tahun. Aktivitas literasi keluarga Suku Baduy tidak lepas dari budaya dan kepercayaan yang mereka anut. Kebudayaan tersebut diturunkan secara turun temurun dengan
\end{abstract}


pendekatan intergenerational learning, yaitu proses penyampaian literasi yang dipraktekkan langsung didalam keluarga.

Kata Kunci: etnografi, intergenerational learning, literasi keluarga, suku Baduy

\section{PENDAHULUAN}

Suku Baduy pada hakikatnya adalah kelompok masyarakat yang rajin belajar, dengan setiap hari pergi ke ladang. Cara belajar mereka dengan praktik kerja sehingga bekerja dimaknai dengan belajar. Orang yang belajar di lembaga pendidikan, menurut pandangan pemuka adat Suku Baduy akan meninggalkan waktu kerja. Di samping itu, orang yang sudah lulus sekolah umumnya tidak mau bekerja di ladang. Dengan persepsi tersebut, sampai sekarang masyarakat adat Suku Baduy dilarang belajar di pendidikan formal atau sekolah seperti orang kota. Namun bukan berarti anak-anak suku Baduy tidak pernah belajar sepanjang hidupnya. Sebaliknya, mereka belajar dari kehidupan yang diturunkan para leluhurnya melalui budaya belajar didalam keluarga, masyarakat dan pemuka adat. Proses belajar seperti ini dinamakan dengan pendekatan pembelajaran antar generasi. Sejatinya, tidak ada definisi tunggal mengenai terminologi "intergenerational learning” atau pembelajaran antar generasi. Intergenerational learning dapat juga disebut family literacy atau literasi keluarga yang bertujuan untuk mendukung terjadinya proses belajar dalam keluarga atau konteks rumah, dan di lingkungan dimana masyarakat berada (UNESCO Institute for lifelong learning, 2015). Lebih kanjut, literasi keluarga adalah penggunaan praktik-praktik situasi sosial, historis dan kultural yang terjadi dalam keluarga (Arsa, Atmazaki, \& Juita, 2019). The European Network for Intergenerational Learning (ENIL) mendefinisikan pembelajaran antar generasi sebagai "a learning partnership based on reciprocicy and mutually involving people of different ages where the generations work together to gain skills, values and knowledge” (Kernan \& Cortellesi, 2019).

Aktifitas literasi keluarga sangat mendukung para orang tua, yang karena berbagai faktor tidak pernah atau sampai selesai mengenyam pendidikan formal, begitu juga dengan anak-anaknya. Sehingga, kegiatan literasi keluarga diharapkan bertujuan untuk mendorong dan membudayakan terjadinya masyarakat belajar (learning society) didalam keluarga atau konteks pembelajaran informal, bukan hanya pada konteks formal seperti persekolahan (Sánchez, Whitehouse, \& Johnston, 2018). Kaplan dkk menjelaskan manfaat utama dari family literacy atau intergenerational learning, yaitu terkait dengan peningkatan modal sosial dalam sebuah masyarakat melalui praktik pembelajaran seumur hidup (Kaplan, Kusano, Tsuji, \& Hisamichi, 1998). Literasi keluarga pada Suku Baduy juga bertujuan untuk mempertahankan dan memelihara sistem sosial masyarakat. Sistem belajar asli (indegeneous learning system), secara tradisional digunakan untuk memenuhi keperluan-keperluan praktis dan untuk meneruskan warisan sosial budaya dan keterampilan dari generasi ke generasi (Coombs, 1973). Pembelajaran yang terjadi pada antar generasi juga merupakan kendaraan sosial yang menciptakan pertukaran sumber daya (Lase, 2020).

Aktifitas literasi keluarga (family literacy) pada Suku Baduy mengedepankan penggunaan model pendidikan papagahan atau saling mengajari antar anggota keluarga dan antar warga masyarakat. Dimana budaya lisan sangat mempengaruhi pola dan pemahaman terhadap proses pendidikan pada Suku Baduy. Hal ini berbeda dengan makna literasi menurut Badan Pengembangan dan Pembinaan Bahasa (Arsa et al., 2019) yang mendefinisikan literasi sebagai kemampuan menulis dan membaca, atau pengetahuan dan 
keterampilan dalam bidang atau aktifitas tertentu. Pada Suku Baduy, tidak ada aturan adat dalam bentuk tulisan dapat ditemukan. Sehingga, definisi literasi keluarga dalam penelitian ini merupakan penyerapan informasi berbentuk ilmu pengetahuan dari lisan dan teks. Literasi keluarga ditujukan untuk menumbuhkembangkan kemampuan kognisi dan sikap pada anakanak Suku Baduy.

Penelitian mendalam tentang pendidikan keluarga pada Suku Anak Dalam telah dilakukan oleh beberapa peneliti, diantaranya kajian literasi anak usia dini pada Suku Anak Dalam Dharmasraya (Arsa et al., 2019), dan kajian adat dan religi Suku Anak Dalam di Bukit Dua Belas (Sager, 2008). Namun belum ada penelitian tentang bagaimana literasi keluarga Suku Anak Dalam dapat dipandang sebagai pembelajaran antar generasi, yaitu pembelajaran yang turun temurun dilakukan oleh orang tua kepada anaknya. Selain itu, karena tidak adanya budaya belajar melalui teks oleh Suku Baduy, menyebabkan sulitnya mengidentifikasi buktibukti teks aktivitas literasi keluarga pada Suku Baduy. Hal inilah yang melatarbelakangi pentingnya mendokumentasikan praktik-praktik kegiatan literasi keluarga yang dilakukan oleh masyarakat Suku Baduy. Untuk itu penelitian ini bertujuan untuk menemukenali praktikpraktik literasi keluarga Suku Baduy yang menggunakan pendekatan pembelajaran antar generasi. Praktik-praktik literasi keluarga Suku Baduy perlu untuk didokumentasikan, sehingga dapat dijadikan acuan bagi pemerintah lokal dalam menyusun program literasi keluarga (family literacy and learning program). Hal ini sangat berguna untuk mendukung pelestarian budaya sekaligus memproteksi praktik-praktik keluarga berbasis adat. Dengan melihat praktik-praktik literasi keluarga menggunakan konsep intergenerational learning, maka akan terlihat relasi antara dua generasi, tua dan muda, yang dapat memberikan manfaat untuk keduanya (Sharma, 2017). Kolaborasi antar generasi memberikan keuntungan signifikan bagi produktifitas orang yang yang terlibat, walaupun mereka berbeda generasi (Lupou, Dorobanțu, \& Fiore, 2010). Pembelajaran antargenerasi juga dapat mendorong kohesi komunitas (Kernan \& Cortellesi, 2019).

\section{METODE}

Pendekatan penelitian yang dipakai adalah pendekatan kualitatif etnografi. Menurut Creswell (2013) penelitian etnografi merupakan salah satu strategi penelitian kualitatif yang dimana peneliti menyelidiki suatu kelompok kebudayaan di lingkungan yang alamiah dalam periode waktu yang cukup lama dalam pengumpulan data utama, data observasi, dan data wawancara. Penelitian ini dilakukan di wilayah ulayat Baduy, Desa Kanekes, Kecamatan Leuwidamar, Kabupaten Lebak, Provinsi Banten. Secara khusus, studi lapangan dilakukan di Baduy Dalam yaitu di Kampung Cibeo dan Kampung Cikeusik, dan Baduy Luar yaitu di Kampung Balingbing dan Kampung Marengo. Perbedaan yang paling paling mendasar dari Baduy Dalam dan Baduy Luar adalah dalam menjalankan pikukuh atau aturan adat saat pelaksanaannya. Masyarakat di Baduy Dalam masih memegang teguh adat dan menjalankan aturan adat dengan baik. Sebaliknya, tidak dengan masyarakat di Baduy Luar yang cenderung lebih terbuka menerima perubahan dan perkembangan.

Metode pengumpulan data yang digunakan dalam penelitian ini adalah wawancara etnografis. Wawancara etnografis merupakan jenis peristiwa percakapan (speech event) yang khusus. Peneliti melakukan wawancara etnografis dengan orang tua (yang terdiri dari ayah dan ibu) dari 16 keluarga dan 18 anak-anak dan remaja di tempat tinggal mereka dengan menyesuaikan diri dengan kegiatan yang sedang dilakukan oleh yang di wawancara. Tiga 
unsur yang penting dalam wawancara etnografis adalah tujuan yang eksplisit, penjelasan, dan pertanyaannya yang bersifat etnografis.

Tahapan penelitian dideskripsikan sebagai berikut (Meriam, 1998). Tahap pertama, pra lapangan yaitu memilih situasi sosial dan menetapkan informan. Tahapan ini menghasilkan hal-hal yang perlu dipersiapkan sebelum penelitian lapangan dilaksanakan. Tahap kedua, peneliti memasuki situasi sosial atau tahapan pekerjaan lapangan, yakni melakukan tahap observasi, wawancara, dan dokumentasi. Pada tahap ini peneliti sudah mulai merencanakan analisis domain. Tahap terakhir yaitu melakukan observasi terfokus untuk menemukan tema literasi keluarga atau literasi antar generasi dengan membuat catatan etnografis. Sebuah catatan etnografis meliputi catatan lapangan dan benda lain yang mendokumentasikan suasana budaya yang dipelajari. Analisa dalam penelitian etnografi ini mengacu pada apa yang dikemukakan oleh Spradley, dengan mengacu pada empat tahap analisis data etnografi (Spradley, 1994). Tahap pertama, peneliti melakukan analisis domain. Analisis ini dilakukan terhadap data yang diperoleh dari wawancara atau pengamatan deskriptif yang terdapat dalam catatan lapangan. Tahap kedua, peneliti melakukan analisis taksonomi, yaitu penjabaran secara rinci dari analisis domain. Tahap ketiga, peneliti melakukan analisis komponensial, yaitu meliputi keseluruhan proses mengorganisasi data hasil wawancara dan catatan lapangan. Tahap terakhir yaitu analisis tema. Dalam tahap ini, peneliti mencari "benang merah" yang mengintegrasikan domain atau kategorisasi data. Sehingga dapat tersusun suatu "konstruksi bangunan" hasil penelitian dalam bentuk tema mengenai situasi sosial atau obyek penelitian.

\section{PEMBAHASAN}

\section{Milestone Pembelajaran Bagi Anak Baduy}

Suku Baduy merupakan salah satu suku yang ada di pedalaman Indonesia, tepatnya di desa Kanekes, Kabupaten Lebak, Provinsi Banten. Suku Baduy terbagi menjadi dua, yaitu suku Baduy Dalam dan suku Baduy Luar. Baduy Dalam adalah bagian dari keseluruhan suku Baduy. Tidak seperti Baduy Luar, masyarakat Baduy Dalam masih memegang teguh adat istiadat nenek moyang. Hal ini dilakukan untuk menjaga kemurnian adat istiadat dan kebudayaan yang ada di suku Baduy. Sebaliknya, Baduy Luar dianggap sebagai penyaring atau benteng agar modernitas tidak secara langsung memasuki Baduy Dalam. Sehingga, apa yang disebut Baduy murni, baik adat maupun orangnya tetap masih ada. Suasana alam di Baduy dikelilingi hutan rimba yang didalamnya terdapat pepohonan yang rindang. Masyarakat baduy baik Baduy Dalam dan Baduy Luar merupakan masyarakat yang homogen.

Masyarakat suku Baduy menganggap pendidikan merupakan hal yang dilarang bagi mereka. Bagi sebagian besar masyarakat Baduy, khususnya kokolot atau orang tua, pendidikan merupakan hal yang bisa merenggut kebudayaan mereka. Para kokolot masih banyak yang menganggap bahwa pendidikan merupakan hal yang bisa merenggut kebudayaan asli mereka. Dalam anggapan masyarakat Baduy, orang pintar identik dengan kecurangan, korupsi, koloni, dan hal-hal buruk lainnya. Sehingga ketua adat dan para kokolot melarang dan menolak ketika ada yang hendak memberikan pendidikan kepada anak-anak mereka, khususnya terjadi di Baduy Dalam. Sutoto (2017) menjelaskan bahwa sebenarnya penolakan terhadap pendidikan formal hanya akan berakibat negatif pada eksistensi masyarakat pada suku pedalaman Namun, bukan berarti anak-anak suku Baduy tidak pernah belajar. Suku Baduy pada hakikatnya adalah kelompok masyarakat yang rajin belajar, dengan setiap hari pergi ke buma. 
Cara belajar mereka dengan praktik kerja sehingga bekerja dimaknai belajar dan dilakukan melalui proses latihan atau pengalaman (George \& Jones, 2014). Masyarakat Baduy juga belajar dengan orang luar karena mereka sangat terbuka dengan wisatawan yang berkunjung. Hampir tiap hari ada saja wisatawan yang datang berkunjung ke Baduy Luar dan Baduy Dalam, termasuk menginap di rumah-rumah masyarakat. Interaksi yang terjadi antara wisatawan dan masyarakat Baduy, termasuk anak-anak memberikan manfaat positif bagi anak-anak Baduy. Walaupun tidak semuanya, beberapa anak-anak dan orang tua Baduy ada yang mampu berhitung dan membaca dari hasil interaksi dan transaksi ekonomi dengan para wisatawan. Transaksi ekonomi dilakukan seputar jual beli makanan dan biaya sewa menginap di rumah warga Baduy.

Walaupun demikian, pendidikan untuk anak-anak Baduy dilakukan secara turun temurun dari orang tua kepada anaknya, yang dikenal dengan intergenerational learning atau family literacy (Hanemann, Mccaffery, Newell-jones, \& Scarpino, 2017). Literasi keluarga dikonseptualisasikan sebagai proses informal yang terjadi melalui dalam keluarga. Putnam (1993) menjelaskan hubungan dan proses informal pembelajaran ini ke dalam teori pembelajaran antar generasi. Anak-anak Suku Baduy belajar tentang menjaga lingkungan dengan tidak merusak hutan dan membuang sampah di sungai, serta membunuh hewanhewan liar, diluar yang di konsumsi. Anak-anak Baduy belajar menenun, membuat kerajinan, berkebun, memanjat pohon membuat koja dan alat-alat kebutuhan hidup lainnya dengan melihat langsung orang tuanya dalam keseharian. Kemudian, mereka diajarkan orang tuanya bagaimana cara berkebun, membuat kerajinan dan lainnya. Hal ini terjadi setiap hari. Bagi anak-anak Baduy, sekolah terbaik untuk mereka adalah alam dan budaya. Dalam hal ini, keluarga memiliki peranan penting dalam kehidupan anak (Inten, 2017).

Kegiatan literasi keluarga pada Suku Baduy berlangsung sepanjang hayat. Bayi usia 7 hari mulai diperkenalkan pada alam sekitar, yaitu ke buma atau ladang. Setiap hari, para orang tua menempatkan bayinya di ayunan sambil mereka bekerja di huma. Sebuah golok atau pisau besar akan ditempatkan disamping ayunan untuk bayi laki-laki, dengan makna agar anak mereka kelak terbiasa bekerja di buma. Sementara untuk anak perempuan diberikan kored atau arit (sejenis pisau melengkung) dengan harapan kelak anak perempuan tersebut terbiasa membantu orang tua atau suaminya membersihkan huma dari rumput liar. Mulai usia 3 tahun, terdapat perbedaan aktivitas belajar anak laki-laki dan perempuan. Anak laki-laki mulai diajarkan nyacar atau membersihkan rumput liar di buma. Sementara anak perempuan diajarkan untuk meniup hau atau tungku memasak tradisional dengan menggunakan kayu sebagai bahan bakar. Pada usia ini juga baik anak laki-laki maupun anak perempuan mulai diperkenalkan dengan aat musik tradisional, contohnya angklung, suling dan kecapi. Anakanak usia 3 tahun terlebih dahulu dibiasakan untuk menonton pertunjukkan musik tradisional yang dimainkan anak-anak usia 7 tahun keatas yang dikoordinir oleh pelatih yang telah dipilih jaro atau ketua adat.

Pada usia 5 tahun, anak-anak laki-laki mulai diajarkan membuat lodong (semacam wadah bamboo untuk mengambil air di sungai), sair (wadah yang terbuat dari bamboo untuk membawa alat makan atau perabot kecil lainnya), dan hateup (atap rumah yang dibuat dari daun arena atau kiray). Sedangkan anak perempuan di usia 5 tahun diajarkan dan diberi tanggung jawab untuk mengambil air di sungai dan memasaknya untuk air minum seluruh keluarga. Pada usia ini pula, baik anak laki-laki maupun perempuan mulai diajarkan berhitung dengan menggunakan media alam seperti buah-buahan, ranting, atau lidi. Para orang tua biasanya mengajarkan tentang kemampuan berhitung di buma saat orang tua mau menghitung 
hasil panen. Kegiatan literasi pada usia ini biasanya menggunakan pola bercerita sesuai dengan konsep literasi awal pada anak usia dini, yaitu dengan menggali pengetahuan anal lewat menceritakan pengalaman keseharian yang dilakukannya (Fajriyah, 2018).

Selanjutnya pada usia 10 tahun, anak laki-laki diajarkan gotong royong, seperti membangun jembatan atau lexit (rumah bambu) dan membuat alat-alat rumah tangga, seperti gelas, lodong, sair yang terbuat dari bambu dan kayu. Adapun anak perempuan mulai diajarkan menjahit baju dengan menggunakan tangan. Anak perempuan juga mulai diajarkan ngakeul atau mengaduk nasi supaya dingin. Pada usia ini, baik anak laki-laki maupun perempuan mulai diajarkan tentang aturan adat Baduy oleh Jaro atau ketua adat. Anak-anak Baduy dikumpulkan di alun-alun oleh Jaro setiap dua bulan sekali untuk diberikan arahan dan pengajaran adat tentang silih asab, asih, asub agar tidak dilanggar. Nilai-nilai adat ini mengajarkan anak-anak Baduy agar saling mengasihi, menghormati dan menjaga satu sama lain. Tujuannya adalah agar terciptanya hidup yang harmonis di masyarakat suku Baduy. Anak-anak juga diajarkan untuk mengikuti aturan adat Baduy, diantaranya tidak diperbolehkan memakai baju warna-warni, dilarang sekolah, dilarang merokok, tidak boleh memakai sabun, dan tidak boleh naik kendaraan. Larangan-larangan tersebut dijelaskan berikut makna atau arti dibalik aturan adat tersebut.

Pada usia 12 tahun, anak laki-laki mulai dilatih untuk memanjat pohon dan membantu memanen hasil tani di huma. Namun, terkadang perempuan juga membantu bersama-sama (Muttaqien, 2019). Seiring dengan tingginya jumlah kunjungan orang luar yang ingin mengenal Suku Baduy, anak laki-laki pada usia ini mulai diajarkan jadi pemandu turis (guide), dengan tugas mengajak pengunjung suku Baduy untuk berkeliling di desa-desa pada lingkungan masyarakat Baduy. Sedangkan anak perempuan secara mandiri mulai belajar dan diberi tanggung jawab untuk memasak, mencuci baju dan alat makan, membuat baju untuk keluarga (seperti untuk bapak, ibu, kakak dan adik). Dan secara mandiri memiliki tugas untuk mencari kayu bakar untuk keperluan memasak. Kemudian pada usia 15 tahun, anak laki-laki diberi kepercayaan untuk mengurus buma (seperti bercocok tanam dan ngored atau membersihkan huma) dan diberikan kepercayaan untuk keluar dari wilayah suku Baduy dan mengunjungi kota lain untuk tujuan berdagang atau melakukan perjalanan wisata. Sementara anak perempuan bertanggung jawab untuk mengerjakan pekerjaan-pekerjaan rumah tangga. Pada usia 15-16 tahun, umumnya remaja perempuan maupun laki-laki akan menikah dengan sepupu sendiri dengan memakai sistem perjodohan (Iskandar \& Iskandar, 2017; Zid, Hidayat, \& Mukhtar, 2018).

Tabel 1. Milestone Pembelajaran Bagi Anak Baduy

\begin{tabular}{|c|c|c|c|}
\hline \multirow{2}{*}{$\begin{array}{c}\text { Tahapan } \\
\text { Perkembangan } \\
\text { Usia }\end{array}$} & \multicolumn{2}{|c|}{ Aktivitas Belajar } & \multirow{2}{*}{$\begin{array}{l}\text { Sumber } \\
\text { Belajar }\end{array}$} \\
\hline & Laki-laki & Perempuan & \\
\hline Batita & dibawa ke buma & dibawa ke huma & Alam \\
\hline 3 tahun & $\begin{array}{l}\text { nyacar } \\
\text { bermain alat musik } \\
\text { tradisional }\end{array}$ & $\begin{array}{l}\text { meniup hau } \\
\text { bermain alat musik } \\
\text { tradisional }\end{array}$ & $\begin{array}{l}\text { Orang tua } \\
\text { Jaro }\end{array}$ \\
\hline 5 tahun & $\begin{array}{l}\text { Membuat lodong, sair, } \\
\text { hateup, } \\
\text { belajar berhitung dengan }\end{array}$ & $\begin{array}{l}\text { Mengambil dan memasak } \\
\text { air } \\
\text { belajar berhitung dengan }\end{array}$ & Orang tua dan \\
\hline
\end{tabular}


10 tahun

12 tahun

15 tahun

17 tahun media alam.

Gotong royong dan membuat alat-alat rumah tangga

Memanjat pohon, panen tani, pemandu turis

Diberi kepercayaan mengurus huma, keluar baduy menikah media alam

Menjahit baju dan ngakeul

teman sebaya

Orang tua

Memasak, mencuci, mencari kayu bakar

Orangtua dan teman sebaya Mengerjakan tugas-tugas rumah tangga Orang tua

Sumber: diolah dari hasil penelitian

\section{Kegiatan Literasi Keluarga Suku Baduy}

Kegiatan literasi keluarga pada Suku Baduy dimulai sejak ratusan tahun yang lalu ketika pertama kali mereka tinggal di Baduy. Aktivitas literasi keluarga Suku Baduy tidak lepas dari budaya dan kepercayaan yang mereka anut. Kebudayaan tersebut diturunkan secara turun temurun dengan pendekatan intergenerational learning (Corrigan, Mcnamara, \& O'Hara, 2013), yaitu proses penyampaian literasi yang dipraktikkan langsung didalam keluarga maupun masyarakat yang mengarah pada terciptanya proses transformasi budaya dan pendidikan. Pendidikan antar generasi memungkinkan adanya interaksi belajar yang multi arah bagi orang yang terlibat, seperti anak dapat belajar pada orang tua, orang tua belajar dari anaknya, anak belajar dari saudaranya, dan keluarga yang lain (UNESCO, 2020). Ada beberapa media yang digunakan oleh masyarakat Baduy Dalam dan Baduy Luar sebagai alat melestarikan kebudayaan dan juga mengajarkan pendidikan kepada anak-anak Suku Baduy. Sumber literasi yang digunakan untuk media dalam kegiatan literasi Suku Baduy terkait dengan hasil budaya Suku Baduy itu sendiri, baik dalam bentuk materil maupun immaterial. Sumber literasi tersebut diantaranya lagu dan kesenian, cerita legenda atau cerita rakyat, pantun, dan permainan tradisional.

Masyarakat Suku Baduy menggunakan lagu dan kesenian sebagai alat upacara adat kegiatan hiburan dalam perayaan pernikahan. Menurut Bapak Santra (26 tahun), penduduk asli Suku Baduy yang memiliki seorang anak, mengatakan bahwa anak-anak sudah mengenal kesenian dan lagu Baduy sejak mereka lahir. Anak-anak diajarkan lagu dan kesenian Baduy sejak usia 3 tahun. Lagu yang biasa diajarkan yaitu lagu Baduy Cikarile dan Kidung. Anakanak juga diajarkan untuk menguasai alat-alat musik berupa angklung, kecapi, dan suling. Jaro atau kepala rombongan mengajari anak-anak Suku Baduy setiap 2 minggu sekali dengan menggunakan metode mendengar. Anak-anak akan diperlihatkan terlebih dahulu cara menyanyikan lagu dan memainkan alat musik setelah beberapa minggu mereka akan mempraktikkannya dengan teman sebaya. Dalam kesenian Baduy, tidak ada not ataupun notasi seperti halnya musik pada umumnya. Permainan musik lebih mengutamakan penggunaan rasa dan bermain dengan kekuatan ingatan. Praktik ini sudah berjalan dari generasi ke generasi dan terus dilestarikan hingga saat ini. Kesenian ini biasanya memiliki perkumpulan atau paguyuban anak-anak dan pemuda Baduy.

\section{Sumber Literasi}

Sumber literasi lain yang dipakai untuk mengajarkan budaya Suku Baduy adalah cerita legenda atau cerita rakyat yang dilestarikan dan tetap diajarkan pada anak-anak Suku 
Baduy hingga saat ini. Diantara cerita legenda tersebut adalah kisah tentang Nyai Sri, yaitu kisah yang menceritakan tentang dewi padi yang memberikan dan menjadi sumber makanan bagi masyarakat Suku Baduy. Legenda diceritakan secara turun-temurun oleh para orang tua pada anak-anaknya. Literasi di Suku Baduy sama sekali tidak menggunakan tulisan sebagai media pembelajaran. Umumnya hanya menggunakan kemampuan mendengar, menghapal dan memahami. Seperti halnya legenda, pantun juga merupakan salah satu sumber literasi Suku Baduy. Salah satu pantun Baduy yang terkenal adalah pantun kidung. Tidak sembarang orang bisa memainkan pantun di Baduy, begitu juga dengan anak-anak, tidak semuanya diajarkan secara khusus untuk bisa berpantun. Anak-anak Suku Baduy mengetahui dan belajar langsung pada tukang pantun hanya pada hari-hari besar tertentu. Pantun pun tidak secara khusus diajarkan orang tua kepada anaknya.

Literasi keluarga Suku Baduy yang terakhir yaitu berkaitan dengan literasi bahasa. Bahasa sehari-hari yang digunakan oleh masyarakat Suku Baduy adalah bahasa sunda. Bahasa sunda sudah digunakan sejak zaman nenek moyang sebagai alat komunikasi dan terus dilestarikan hingga saat ini. Adapun cara orang tua mengajarkan bahasa sunda kepada anaknya tidak jauh berbeda dengan orang lain, yaitu dengan pembiasaan komunikasi setiap hari. Penguasaan bahasa adalah pembawaan lahir pada anak-anak, meskipun tidak belajar secara khusus, tetapi melalui interaksi dengan lingkungan dimana anak tinggal (Wartomo, 2017). Seiring banyaknya wisatawan yang datang ke daerah Baduy, banyak anak-anak yang mulai mengenal bahasa Indonesia. Banyak para wisatawan yang tidak bisa berbahasa sunda, sehingga secara perlahan anak-anak Suku Baduy belajar berkomunikasi dengan bahasa Indonesia. Tidak ada larangan bagi anak-anak Suku Baduy untuk belajar kebudayaan luar, termasuk penguasaan bahasa selain bahasa Sunda, Namun, mereka diperingatkan untuk tidak melupakan kebudayaan Baduy. Seperti pepatah Baduy yang berbunyi "lojor ulah dipotong, pondok ulab disambung" - artinya panjang jangan di potong, pendek jangan di sambung. Pepatah tersebut mengandung makna, budaya dan kebijaksanaan yang ada di Baduy dari zaman dahulu hingga saat ini tidak boleh ditinggalkan ataupun ditambah dengan kebudayaan luar. Anak muda suku Baduy mematuhi pikukuh atau petuah orang tua (Sholih, Rosmilawati, \& Darmawan, 2020). Ketaatan pada keyakinan dan aturan adat adalah salah satu faktor kunci integrasi masyarakat Baduy (Jacobs, 2012)

Literasi keluarga Suku Baduy berbeda dengan konteks masyarakat yang lain. Masyarakat Suku Baduy menjalankan proses pendidikan keluarga disesuaikan dengan amanat leluhurnya, yaitu dengan menjalankan sebuah proses pendidikan dengan model dan bentuk khusus. Keluarga pada Suku Baduy telah mengembangkan sendiri pendidikan tradisi melalui sistem belajar asli (indigenous learning) dalam proses transaksi dan adaptasi dengan lingkungan sekitar. Proses belajar seperti ini dapat dipahami dengan menggunakan konsep experiential learning dari Kolb (1984). Menurut Kolb, belajar adalah suatu proses dimana pengetahuan dibangun melalui transformasi pengalaman. Proses pendidikan experiential learning merupakan proses belajar yang manusiawi (sesuai dengan kodrat dan perkembangan manusia). Substansi atau materi literasi keluarga pada masyarakat Suku Baduy diajarkan oleh orang tua secara turun temurun dan sesuai kebutuhan hidup. Aspek aturan hidup, ekonomi, sosial, serta lingkungan merupakan materi pelajaran yang diajarkan bagi semua anak-anak Suku Baduy. Belajar aturan hidup merupakan dasar pelajaran yang harus diketahui semua anak-anak Suku Baduy. Aturan hidup merupakan payung dari seluruh aktivitas. Walaupun suku Baduy memiliki makna dan kegiatan tersendiri mengenai literasi keluarga, namun pada dasarnya penguasaan literasi pada setiap aspek kehidupan merupakan tolak ukur kemajuan peradaban 
suatu bangsa (Permatasari, 2015). Praktek pembelajaran antargenerasi juga membantu untuk terbentuknya modal sosial di masyarakat (Coull, 2018).

\section{KESIMPULAN}

Literasi keluarga (family literacy) merupakan istilah yang menjadi bagian dari literasi secara umum yang popular di Indonesia. Landasan dasar yang menjadi akar filosofi dari istilah literasi keluarga sebagai bagian dari metode pendidikan berangkat dari asumsi bahwa "orang tua adalah guru pertama bagi anak-anak". Pendekatan literasi keluarga yang digunakan pada masyarakat Suku Baduy adalah informal yang dilakukan di rumah-rumah maupun praktik di lapangan, diantaranya di huma. Masyarakat Baduy memiliki aktivitas literasi keluarga sendiri, dimana bagi anak-anak sebelum usia 10 tahun mereka dibimbing oleh orang tua masing-masing. Literasi tentang aturan hidup, ekonomi, sosial serta lingkungan merupakan materi yang diajarkan orang tua kepada anak-anaknya. Aktifitas literasi keluarga dalam keluarga tradisional bersifat informal dan terjadi melalui interaksi multi-generasi yang alami. Sebaliknya, pada masyarakat modern yang kompleks, banyak keluarga yang tidak lagi mentransmisikan pengetahuan ini, dan semakin hilang atau proses harus terjadi di luar keluarga. Upaya mendorong terbentuknya masyarakat belajar dalam konteks pembelajaran informal menjadi penting untuk masyarakat Suku Baduy, agar mereka dapat mempertahankan eksistensinya.

\section{DAFTAR RUJUKAN}

Arsa, D., Atmazaki, A., \& Juita, N. (2019). Literasi Awal pada Anak Usia Dini Suku Anak Dalam Dharmasraya. Jurnal Obsesi: Jurnal Pendidikan Anak Usia Dini, 3(1), 127. https://doi.org/10.31004/obsesi.v3i1.159

Coombs, P. H. (1973). New Paths to Learning for Rural Children and Youth. New York,NY: International Council for Educational Development.

Corrigan, T., Mcnamara, G., \& O’Hara, J. (2013). Intergenerational Learning: A Valuable Learning Experience for Higher Education Students. Egitim Arastirmalari-Eurasian Journal of Educational Research, 13(52), 117-136.

Coull, Y. (2018). Learning Through Intergenerational Practice Generations Working Together 2 Learning Through Intergenerational Practice. Retrieved from http://generationsworkingtogether.org/downloads/5252d276ca45a-GWT brochure FINAL.pdf

Creswell, J. W. (2013). Qualitative inquiry \& research design: choosing among five approaches (3rd ed.). Thousand Oaks, California: Sage Publications.

Fajriyah, L. (2018). Pengembangan Literasi Emergen pada Anak Usia Dini. Proceedings of The ICECRS.

George, J. M., \& Jones, G. R. (2014). Understanding and managing organizational behaviour. New Jersey: Pearson Education.

Hanemann, U., Mccaffery, J., Newell-jones, K., \& Scarpino, C. (2017). Guidelines for Family Literacy and Guidelines for Family Literacy and Learning Programmes.

Inten, D. N. (2017). Peran Keluarga dalam Menanamkan Literasi Dini pada Anak. Golden Age, 1(1), 23-32. Retrieved from file:///Users/ilarosmilawati/Downloads/26899568-2-PB.pdf 
Iskandar, J., \& Iskandar, B. S. (2017). Local knowledge of the baduy community of south banten (Indonesia) on the traditional landscapes. Biodiversitas, 18(3), 928-938. https://doi.org/10.13057/biodiv/d180309

Jacobs, J. (2012). Orang Baduy dari Banten. Bandung: Primaco Akademika \& Judistira Garna Foundation.

Kaplan, M., Kusano, A., Tsuji, I., \& Hisamichi, S. (1998). Intergenerational Programs: Support for Children, Youth, and Elders in Japan. New York,NY: State University of New York Press.

Kernan, M., \& Cortellesi, G. (2019). Intergenerational Learning in Practice. https://doi.org/10.4324/9780429431616

Kolb, D. A. (1984). Experiential Learning: Experience as the Source of Learning and Development. New Jersey: Prentice Hall.

Lase, D. (2020). Pembelajaran Antargenerasi: Sebuah Kajian Literatur. https://doi.org/10.31235/osf.io/bsja3

Lupou, R., Dorobanțu, A., \& Fiore, F. (2010). A new lifelong learning model based on intergenerational exchange: Premises and foreseen benefits. Procedia - Social and Behavioral Sciences, 2(2), 2761-2765. https:/ / doi.org/10.1016/j.sbspro.2010.03.411

Meriam, S. B. (1998). Qualitative research and case study applications in education (Rev. and expanded. ed). San Francisco, CA: Jossey-Bass.

Muttaqien, Z. (2019). Peran Perempuan dalam Tradisi Sunda Wiwitan. Khazanah Theologia, 1(1), 23-39. https://doi.org/10.15575/kt.v1i1.7123

Permatasari, A. (2015). Membangun Kualitas Bangsa dengan Budaya Literasi. Seminar Nasional Bulan Bahasa UNIB, 146-156. Bengkulu.

Putnam, R. D. (1993). Making Democracy Work: Civic Traditions in Modern Italy. Princeton, N.J: Princenton University Press.

Sager, S. (2008). The Sky is our Roof, the Earth our Floor Orang Rimba Customs and Religion in the Bukit Duabelas region of Jambi, Sumatra. (May). Retrieved from https://openresearch-repository.anu.edu.au/handle/1885/49351

Sánchez, M., Whitehouse, P., \& Johnston, L. (2018). Intergenerational Learning and Education in Schools and Beyond. Journal of Intergenerational Relationships, 16(12), 1-4. https://doi.org/10.1080/15350770.2018.1404380

Sharma, R. (2017). Intergenerational Learning. Journal of Gerontology \& Geriatric Research, 06(03), 9-10. https:/ / doi.org/10.4172/2167-7182.1000432

Sholih, Rosmilawati, I., \& Darmawan, D. (2020). Intergenerational Learning: Valuable Learning Experiences for Baduy Youth. Proceedings of the International Conference on Science and Education and Technology (ISET 2019), 443(Iset 2019), 501-504. Retrieved from https://www.atlantis-press.com/article/125941356

Spradley, J. P. (1994). Participant Observation. New York,NY: Mc. Graw-Hill Book Comparation.

Sutoto. (2017). THE TRANSFORMATION OF BADUY LEARNING CULTURE IN. Jurnal Pendidikan Dan Pengajaran, 50(2), 86-97.

UNESCO. (2020). Unlocking the potential of family and intergenerational learning. In UNESCO Covid-19 Eduaction Response. Retrieved from https://unesdoc.unesco.org/ark:/48223/pf0000373512

UNESCO Institute for lifelong learning. (2015). Learning families: Integrational approaches to literacy teaching and learning. https://doi.org/10.4324/9780203415870 
Wartomo. (2017). Membangun Budaya Literasi Sebagai Upaya Optimalisasi Perkembangan Bahasa Anak Usia Dini. Retrieved from http://repository.uinjkt.ac.id/dspace/bitstream/123456789/36571/2/SAKINAH MAWADAH R-FAH.pdf

Zid, M., Hidayat, R., \& Mukhtar, S. (2018). The model of Baduy's community system to anticipate the social environment change. 22(2), 1-11. 